\title{
MYANMAR
}

\section{Community perceptions of the social and economic impacts of COVID-19 in Myanmar Insights from a National COVID-19 Community Survey (NCCS) - June and July 2020}

\author{
Isabel Lambrecht, Derek Headey, Than Zaw Oo, and Sophie Goudet
}

A community survey based on interviewing community members in 85 urban wards and 223 rural villages was conducted in June and July 2020 across all of Myanmar's states/regions to assess the direct and indirect economic and social impacts of COVID-19. All interview responses refer to community members' perceptions of what is happening in their communities, such that responses are at least partially subjective. Where possible, this report compares results to other household or firm-based surveys.

Key findings

COVID-19 restrictions. Respondents from nearly all interviewed communities stated that there were a range of COVID-19 prevention measures in place, with the most common being curfews, restrictions on social activities, and restrictions or conditions on entry into the village/ward. Potentially more economically costly restrictions on leaving the village/ward for shopping or trade were reported in half of the interviewed communities. Most communities reported closely following COVID-19 regulations.

Economic impacts. Respondents from nearly all communities perceived that COVID-19 caused widespread income loss. Unskilled laborers were viewed to be the most affected group in rural and urban communities, followed by households with young children or elderly members.

Social protection. Encouragingly, almost all respondents stated that government assistance through food-based social protection was present in their community. However, only 20 percent of communities cited this assistance as providing a main coping mechanism, but with variation across states/regions. Individual food donations were strikingly important in urban areas (42 percent), but less so in rural areas (13 percent). Food or cash for work schemes were reported in around one-quarter of communities, being more common in rural areas, except for Rakhine and Chin. Non-food assistance was much less common.

(continued) 
Agricultural production. Of the 223 farming communities, 55 percent reported lower than normal agricultural production. Eighty and 37 percent of respondents in adversely affected farming communities reported bad weather and pests as major constraints, respectively, followed by a series of economic constraints directly or indirectly related to COVID-19, such as low output prices, mobility restrictions, input shortages, or poor access to traders and brokers. Half of farming communities reported greater-than-normal difficulties in selling produce.

Migration and remittances. Many communities reported having households dependent on domestic or overseas migrants and that these households lost income from reduced remittances due to COVID-19 responses. Restrictions on mobility and job losses led many migrants to return home during the first half of 2020 , although others were unable to return despite losing their jobs. All communities reported both female and male migrants returning from overseas and from other parts of Myanmar. Even with recent easing of mobility restrictions, no communities reported new departures for overseas employment. However, domestic migration has resumed with both men and women from the surveyed communities reported to again be leaving their villages to seek work elsewhere in Myanmar.

Health and health services. Encouragingly, respondents did not see signs that their communities are experiencing higher than usual morbidities. However, some respondents mentioned difficulties in visiting health facilities due to COVID-19 related restrictions. Moreover, in many communities, households were reported as choosing not to visit health facilities for fear of contracting the virus.

\section{Introduction}

Myanmar has been fortunate in thus far having one of the lowest caseloads of COVID-19 per population globally, with under 400 confirmed cases as of early August. However, as a developing economy still beset by high rates of poverty and vulnerability, Myanmar is highly susceptible to the economic and social disruptions stemming from COVID-19. These disruptions began with the closure of the Chinese border and the cessation of agricultural exports in late January, followed in February and March by further disruptions to trade, tourism, manufacturing, and remittances. However, an economic simulation analysis by Diao et al. (2020) suggests that the most severe economic impacts of COVID-19 stemmed from the temporary lockdown policies imposed in late March, which - though necessary to prevent the further spread of the virus - led to significant disruptions throughout the economy, including the agri-food sector and the rural economy. Phone survey evidence on agricultural and industrial value chains demonstrates that economic disruptions related to COVID-19 are pervasive and significant (Fang et al, 2020; Goeb, Boughton, and Maredia 2020; Goeb et al. 2020, Takeshima, Win, and Masias 2020a, 2020b). In aggregate, economic simulations predict a modest contraction in Myanmar's gross domestic product in 2020 (compared to rapid growth forecasted in the absence of COVID-19), but a more significant reduction in household incomes at around 12 percent on average. ${ }^{1}$

Despite this evidence, there is still much we do not yet know about the impacts of COVID-19 in Myanmar, either because of the stylized nature of the simulation models used or the very specific focus of most phone-based surveys. On the economic front, Myanmar has an extremely diverse economy that remains predominantly rural but dependent on a range of livelihoods, including crop agriculture, livestock, and fishing; local non-farm employment and small businesses entrepreneurship; and remittances from both abroad and elsewhere in Myanmar. Many urban

\footnotetext{
${ }^{1}$ A related study examined the impact of COVID-19 on remittances, disruptions to which were identified as an important mechanism for increasing poverty rates, especially in regions dependent on international remittances (Diao and Mahrt 2020).
} 
communities and some rural communities are integrated into the faltering global economy, while other rural communities may be relatively isolated both economically and socially. This diversity across communities may result in considerable variation in the interpretation and enforcement of COVID-19 prevention measures. Pure economic studies may also overlook some of the social consequences of the crisis, such as disruptions to healthcare and increased risks associated with non-COVID-19 diseases that still are common in Myanmar (Headey et al. 2020).

To better understand both the economic and social impacts of the COVID-19 crisis on Myanmar's diverse rural and urban communities, we conducted a large-scale community phone survey covering approximately half of Myanmar's 356 townships (Figure 1). Unlike conventional household surveys, we asked respondents not about themselves or their households but about their communities, defined as either a rural village or an urban ward. The specific objectives of the survey were to assess community conditions pertaining to:

- COVID-19 prevention measures;

- Poverty and food insecurity;

- Access to social safety nets or other forms of assistance;

- Migration - inward and outward;

- Disease prevalence and disruption to health services;

- Exposure to different kinds of shocks;

- Problems with agricultural productions and marketing; and

- Priorities for public investments or programs in the local community.

Additionally, we asked about community characteristics in order to classify the communities by diversity in livelihoods and by structural characteristics, such as infrastructure and remoteness.

The remainder of this note covers the data and methods in more detail (Section 2) and key results (Section 3) before turning to potential policy implications (Section 4).

\section{Data and methods}

The first round of the COVID-19 community survey, conducted between 23 June and 16 July 2020, is the first round in a series of phone survey with community members that are expected to be conducted monthly until the end

Figure 1. Townships in Myanmar from which communities were selected for the survey

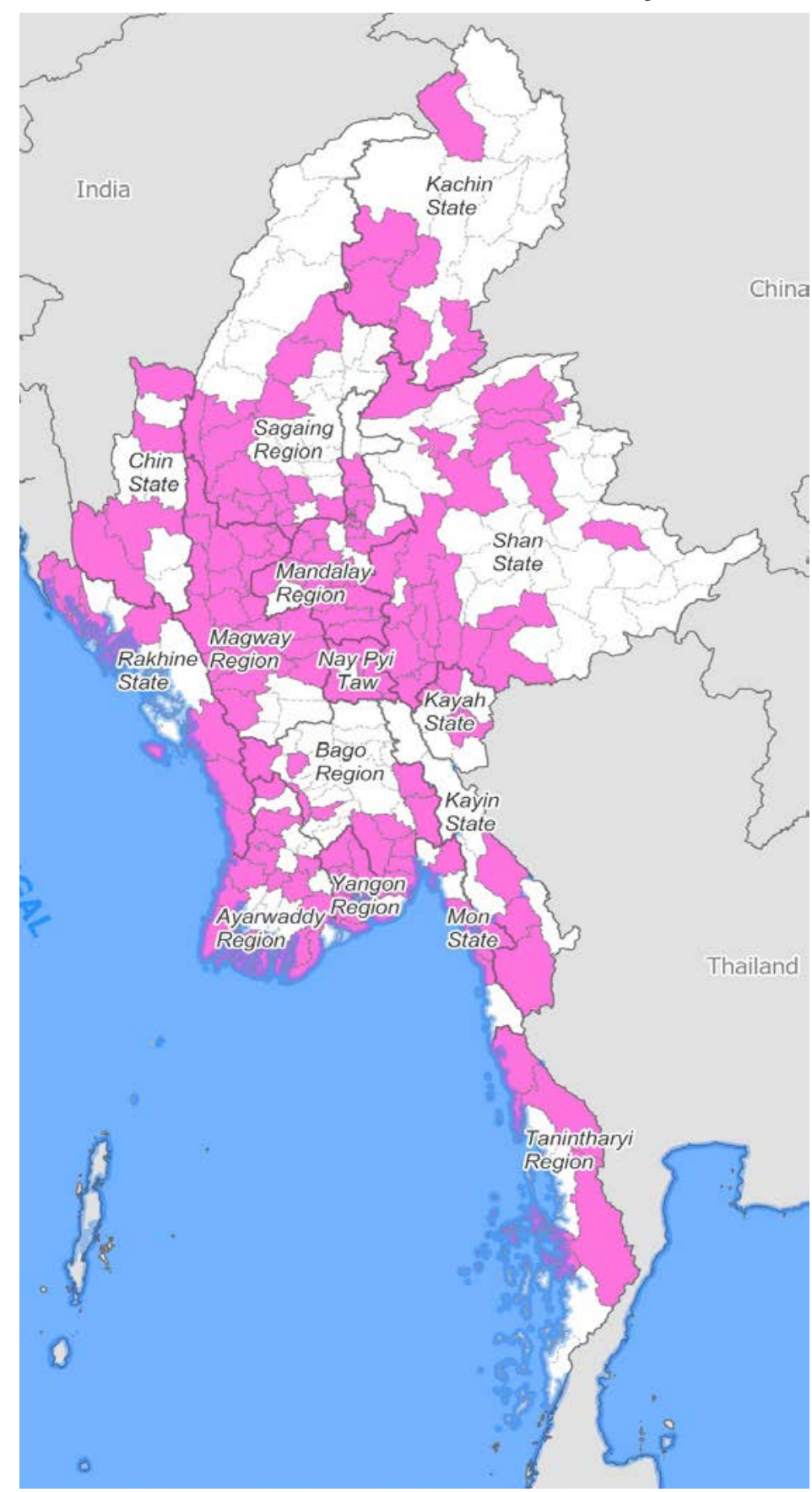

Source: MAPSA National COVID-19 Community Survey - June/July 2020 
of $2020 .^{2}$ The community survey relies on male and female community members in rural and urban areas across the country as informants on their communities. ${ }^{3}$ Survey respondents are residents who have lived in the respective village or ward for at least two years and who are between 18 years and 65 years of age. ${ }^{4}$ They were interviewed over the telephone by trained operators using a structured questionnaire with their responses being entered into an electronic data entry program. In each township, respondents from a maximum of four villages or wards within the township and up to two key respondents per village or ward were interviewed. In total, 561 respondents from 308 communities in 168 townships (out of 356 nationally) participated in the phone survey (Table 1). The 308 communities consisted of 85 urban wards and 223 rural villages, proportions broadly in keeping with Myanmar's urban and rural population shares. The community survey was implemented in parallel with a food vendor survey, the results of which are reported on in a separate policy note (Minten et al. 2020).

Table 1. Number and frequency (percent) of total surveyed respondents, communities, and townships by geographical zone

\begin{tabular}{|c|c|c|c|c|c|c|c|c|c|c|}
\hline \multirow{3}{*}{$\begin{array}{l}\text { Zone } \\
\qquad \text { Region }\end{array}$} & \multirow{2}{*}{\multicolumn{2}{|c|}{ Respondents }} & \multicolumn{6}{|c|}{ Communities } & \multirow{2}{*}{\multicolumn{2}{|c|}{ Townships }} \\
\hline & & & \multicolumn{2}{|c|}{ All } & \multicolumn{2}{|c|}{ Urban } & \multicolumn{2}{|c|}{ Rural } & & \\
\hline & no. & $\%$ & no. & $\%$ & no. & $\%$ & no. & $\%$ & no. & $\%$ \\
\hline South & 168 & 29.9 & 93 & 30.2 & 41 & 48.2 & 52 & 23.3 & 56 & 33.3 \\
\hline Ayeyarwady & 47 & 8.4 & 25 & 8.1 & 0 & 0.0 & 25 & 11.2 & 15 & 8.9 \\
\hline Yangon & 87 & 15.5 & 49 & 15.9 & 36 & 42.4 & 13 & 5.8 & 30 & 17.9 \\
\hline Bago & 34 & 6.1 & 19 & 6.2 & 5 & 5.9 & 14 & 6.3 & 11 & 6.5 \\
\hline Dry Zone & 213 & 38.0 & 118 & 38.3 & 31 & 36.5 & 87 & 39.0 & 62 & 36.9 \\
\hline Magway & 84 & 15.0 & 48 & 15.6 & 12 & 14.1 & 36 & 16.1 & 20 & 11.9 \\
\hline Mandalay & 73 & 13.0 & 39 & 12.7 & 13 & 15.3 & 26 & 11.7 & 22 & 13.1 \\
\hline Sagaing & 36 & 6.4 & 20 & 6.5 & 6 & 7.1 & 14 & 6.3 & 15 & 8.9 \\
\hline Naypyidaw & 20 & 3.6 & 11 & 3.6 & 0 & 0.0 & 11 & 4.9 & 5 & 3.0 \\
\hline South-East & 60 & 10.7 & 32 & 10.4 & 6 & 7.1 & 26 & 11.7 & 16 & 9.5 \\
\hline Mon & 24 & 4.3 & 12 & 3.9 & 4 & 4.7 & 8 & 3.6 & 6 & 3.6 \\
\hline Tanintharyi & 14 & 2.5 & 8 & 2.6 & 2 & 2.4 & 6 & 2.7 & 4 & 2.4 \\
\hline Kayah & 12 & 2.1 & 6 & 1.9 & 0 & 0.0 & 6 & 2.7 & 3 & 1.8 \\
\hline Kayin & 10 & 1.8 & 6 & 1.9 & 0 & 0.0 & 6 & 2.7 & 3 & 1.8 \\
\hline North & 99 & 17.6 & 54 & 17.5 & 7 & 8.2 & 47 & 21.1 & 26 & 15.5 \\
\hline Kachin & 31 & 5.5 & 16 & 5.2 & 3 & 3.5 & 13 & 5.8 & 7 & 4.2 \\
\hline Shan & 68 & 12.1 & 38 & 12.3 & 4 & 4.7 & 34 & 15.2 & 19 & 11.3 \\
\hline West & 21 & 3.7 & 11 & 3.6 & 0 & 0.0 & 11 & 4.9 & 8 & 4.8 \\
\hline Chin & 4 & 0.7 & 2 & 0.6 & 0 & 0.0 & 2 & 0.9 & 2 & 1.2 \\
\hline Rakhine & 17 & 3.0 & 9 & 2.9 & 0 & 0.0 & 9 & 4.0 & 6 & 3.6 \\
\hline TOTAL & 561 & 100.0 & 308 & 100.0 & 85 & 100.0 & 223 & 100.0 & 168 & 100.0 \\
\hline
\end{tabular}

Source: MAPSA National COVID-19 Community Survey - June/July 2020

The respondents were 43 percent female, 44 years old, had lived in the community for 35 years, and estimated they knew 84 percent of all households in their community on average. Respondents were engaged in a range of occupations. In rural villages, 63 percent of the respondents reported farming as their main occupation, while 8 percent are engaged in unskilled work. In urban communities, 19 percent of the respondents reported being unskilled laborers, 17 percent being other service providers, and 11 percent being craftsmen (Appendix Table A.1). The communities

\footnotetext{
${ }^{2}$ Reports on subsequent rounds of the community survey will be published in the Myanmar SSP Policy Note series.

${ }^{3}$ Phone numbers from community members were obtained through different sources, such as through micro-finance organizations of which they are a member or through former research projects in which they were involved. In many communities, village leaders or administrators were the primary point of contact and provided phone numbers of knowledgeable community members who participated in the phone survey.

${ }^{4}$ Only 14 of the 561 respondents had lived for fewer than five years in their respective village/ward.
} 
themselves participate in a diversity of livelihood activities (Appendix Table A.2). Paddy farming was reported to be the main livelihood for 30 percent of all surveyed communities (40 percent of rural communities) and farming of other crops for 26 percent (35 percent of rural communities). For onethird of urban communities, non-farm wage labor was reported as the main income-generating activity, whereas petty trade and street vending were reported as the main activity for 22 percent of urban communities. Rural communities are on average 11 miles away from the nearest town, with one-quarter of rural communities being located more than 15 miles from the nearest town - the most remote community surveyed is 100 miles from the nearest town.

We show descriptive results for the full sample and by rural/urban areas. Where deemed appropriate, we also disaggregate by geographical domains or by state/region. We focus on five geographical domains: (i) Southern Myanmar, including Yangon, Ayeyarwady, and Bago; (ii) Dry Zone, including Mandalay, Magway, Sagaing, and Nay Pyi Taw; (iii) South-East, including Tanintharyi, Mon, Kayin, and Kayah; (iv) North, including Shan and Kachin; and (v) West, including Chin and Rakhine. When there are multiple respondents in the same village or ward, we use the means for that village or ward to calculate community-level information.

Although this survey has diverse geographical coverage and respondents seemed confident in answering most questions, it is important to acknowledge several inherent limitations of this kind of survey. First, the data cannot be considered representative for the country because communities were selected based on the availability of phone numbers through existing contacts. As can be seen in Table 1, Appendix Table A.1, and Figure 1, there is an uneven representation of townships selected in our sample across the states/regions in Myanmar, with systematic gaps particularly related to conflict-affected areas.

Second, in-person community surveys usually utilize a diverse group of community members who answer questions collectively to work towards consensus responses. Since this was not feasible in the context of the COVID-19 pandemic, the present survey relied upon individual community members giving their own perceptions on a diverse range of community conditions. Some respondents may be better informed than others and responses could be sensitive to phrasing or influenced by different response biases related to gender, social position, and knowledge or experience. Therefore, the statistics presented in this report should be considered as community member perceptions rather than as actual conditions on the ground. However, where possible we try to compare results to other household-based phone survey data.

\section{Main results - June and July 2020}

\section{COVID-19 prevention measures}

To avoid the spread of COVID-19, several prevention measures have been implemented across Myanmar. Respondents from every community in our sample stated that that their community had implemented at least one prevention measure (Figure 2).. On average, about seven of the ten specific measures about which respondents were asked were reported to have been implemented in the community at some point in time before the end of June. This included restrictions on outward and inward mobility and on social gatherings. In nearly half of the communities, one or more households had been placed under strict quarantine and were not allowed to leave their home; 84 percent implemented curfews, 39 percent prohibited residents from visiting other homes, and 92 percent restricted social activities and marriage events. 
Figure 2. COVID-19 prevention measures and community adherence, percent

Some households are under strict quarantine and cannot leave their home for a period of time

Residents cannot leave their homes during certain hours of the day or night

Residents need special permission to visit each other's houses

Residents need special permission to get together for social activities

Residents need special permission to hold or participate in marriage activities within the village/ward

Residents cannot leave the village/ward for shopping, except with special permission

Residents cannot leave the village/ward for work or trade, except with special permission

Family/friends from outside the village cannot enter village, except with special permission

Food sellers/traders/brokers cannot enter village, except with special permission

People arriving permanently in the village/ward (or resettling) must undergo quarantine

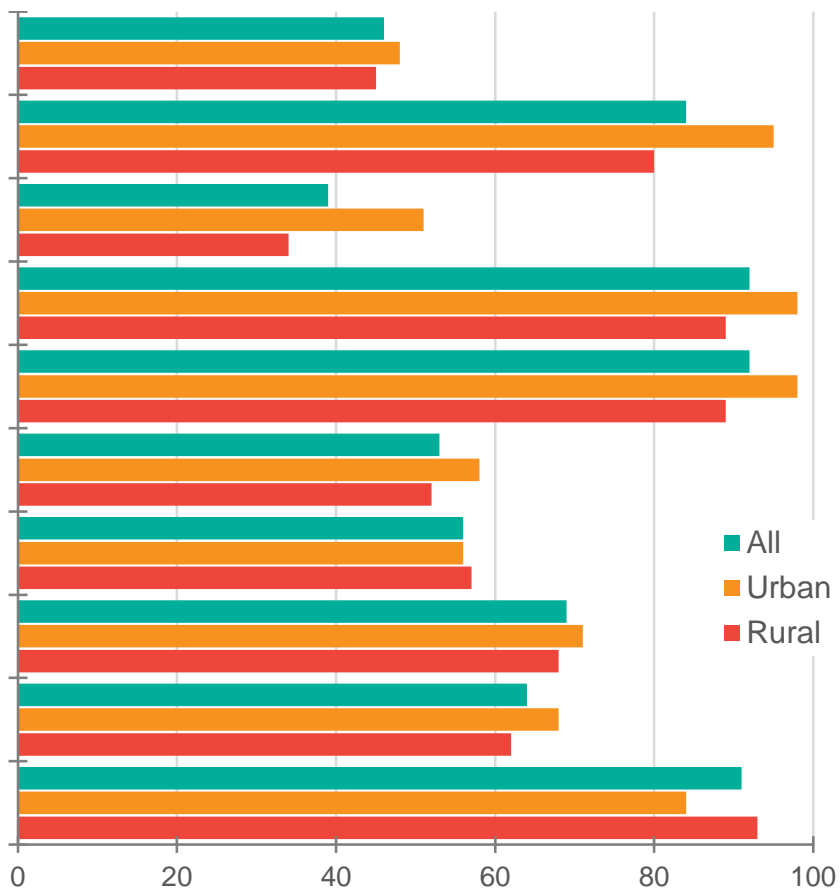

Source: MAPSA National COVID-19 Community Survey - June/July 2020. Responses based on the question 'Which of the following mobility restrictions are currently in place in your village/ward to avoid spreading the COVID-19 virus?'

Residents also appeared to be restricted in their mobility out of the village or ward. In at least half of the communities, residents reportedly were not allowed to leave the village/ward for shopping, work, or trade without special permission (Figure 2). Inward mobility was reported to be even more restrictive; 69 percent of communities restricted entry of family or friends, and 64 percent prohibited entry of food sellers, traders, and brokers. Nine out of ten communities were reported to have quarantine requirements in place for returning migrants or for other people newly arriving in the village.

Measures were imposed at relatively even rates across different geographical areas. When asked whether most community members adhered to COVID-19 restrictions, respondents reported adherence to be very high, with strict adherence in 82 percent of the communities. Perceived compliance was reported to be higher in urban communities ( 87 percent) than in rural communities (80 percent).

\section{Other shocks}

While the COVID-19 pandemic and related mitigation measures affected communities widely, we expected other shocks to adversely impact these communities as well. We thus inquired about other shocks that the community experienced between January and June 2020 (Figure 3).

In a third of the communities, respondents mentioned pests or bad weather as shocks in 2020. However, these shocks particularly affect agricultural activities and, thus, rural communities. Whereas only 10 and 16 percent of urban communities reported pests and bad weather, respectively, 45 and 39 percent of rural villages reported these shocks.

In 2 percent of the sample communities, conflict in 2020 was mentioned. However, our sample does not cover many of the most conflict-affected townships. Perceptions of an increase in crime incidence were low on average (4 percent) but higher in urban (7 percent) than in rural areas; indeed, many respondents reported reduced crime. 
Figure 3. Other shocks reported in the community since January 2020, percent reporting

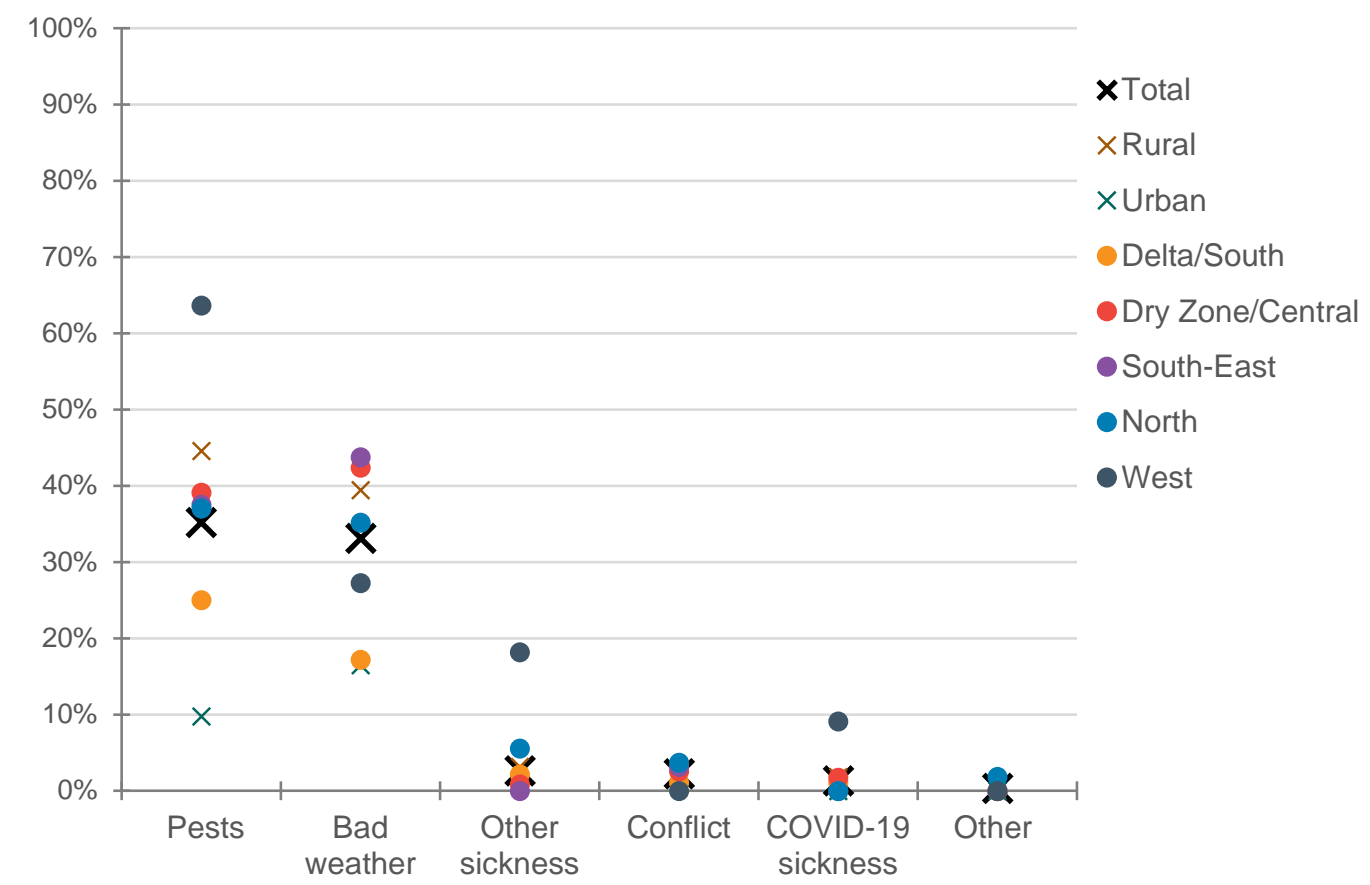

Source: MAPSA National COVID-19 Community Survey - June/July 2020.

Note: Responses to: 'Since January this year, was this village/street from ward badly affected by any of the following shocks, even temporarily? That is, a number of households in the village/street from the ward were affected, not just one or two.'

In line with the relatively low number of confirmed COVID-19 infections recorded by the Ministry of Health, few communities reported sickness due to COVID-19. Only 1 percent of the sample communities reported any cases of sickness, but with a much higher share in the West (9 percent), including Rakhine, which is now struggling with domestic transmission of COVID-19 (Figure 3).

\section{Economic impacts}

To understand how livelihoods have been affected in the communities, we asked respondents to estimate what percentage of households in their community had experienced either a temporary or permanent decline in income between January and June. Respondents estimated that two-thirds of the households in their communities experienced a decline in income over this period. In 20 percent of the communities, respondents estimated that all households suffered a decline in income. The share of households with decreased incomes is similar in urban and rural communities. It is also similar in the different geographic domains, though slightly higher in the South-East (at 74 percent) - a region highly dependent on international remittances, which have declined as a result of COVID-19 - and lower in the North (60 percent).

We also asked which types of households suffered the most from income losses, allowing respondents to list up to three types. Households with casual laborers were mentioned most frequently (91 percent) and at similar rates across different geographies and across rural and urban communities (Table 2). This is consistent with expectations given that casual laborers have no job security and may face highly fluctuating demand for their labor. Previous studies in Myanmar show that landless casual workers, particularly agricultural workers, are the most vulnerable socioeconomic group in rural areas (CSO, UNDP, and World Bank 2020). The economic simulation analysis by Diao and Mahrt (2020a) also predicts greatest income losses among temporary wage workers. Moreover, results from IFPRI's COVID-19 Food Security Survey highlight that respondents from households dependent on unskilled labor are more likely to be poor and food insecure. 
Table 2. Households types reported to be most affected by income losses, percent of communities reporting

\begin{tabular}{lrcc}
\multicolumn{1}{c}{$\begin{array}{c}\text { Main household types } \\
\text { that lost most income }\end{array}$} & Total & Urban & Rural \\
\hline Causal laborers & 91 & 92 & 91 \\
With women and children & 45 & 46 & 45 \\
With elderly people & 35 & 22 & 40 \\
Have non-farm businesses & 23 & 25 & 22 \\
With migrant workers & 18 & 14 & 19 \\
Without agricultural land & 13 & 5 & 17 \\
Female-headed or elder-headed & 11 & 14 & 10 \\
With lower education levels & 11 & 19 & 8 \\
With a farm & 8 & 0 & 11 \\
With person(s) with health condition(s) & 6 & 5 & 6 \\
Subsistence farmers & 6 & 4 & 7 \\
\hline Observations, communities & 308 & 85 & 223 \\
\hline
\end{tabular}

Source: MAPSA National COVID-19 Community Survey - June/July 2020.

Note: Responses based on question 'Please describe up to three types of households that have lost the most income since January 2020'.

Households with young children were also reported to suffer significantly from lost income (reported in 45 percent of the communities) as well as households with elderly people (35 percent). Households with elderly people were more frequently mentioned as being adversely affected by the COVID-19 crisis in rural areas than in urban wards, particularly in the West (73 percent). In nearly a quarter of communities, households with non-farm businesses were also considered to have particularly been affected by income loss - being mentioned at similar frequencies in both urban and rural communities, but much less frequently in the West (9 percent). Somewhat surprisingly, only 18 percent of communities reported households with migrant workers to be notably affected by income loss, but with more frequent mention of such households in rural villages.

We asked respondents what they perceived as the main causes of income declines. Many explained that declining incomes were due to less work for non-farm workers (58 percent) and farm workers (36 percent), less income from non-farm businesses (44 percent) and crop farming (38 percent), and less income from domestic (33 percent) or international migrants (12 percent) (Table 3). All these reasons are likely consequences of COVID-19. However, 6 percent of communities also explicitly mentioned COVID-19 as the cause for declining incomes. Urban-rural differences are greater here, with half of all rural villages mentioning lower income from crop farming as compared to only 10 percent of urban communities. In urban communities, we find a higher emphasis on income loss from loss of work for non-farm workers and in non-farm businesses than is reported in rural villages.

Table 3: Main reasons for declining incomes, percent of communities reporting

\begin{tabular}{lrrc} 
& Total & Urban & Rural \\
Less work or lower wages for non-farm workers & 58 & 64 & 56 \\
Less income from non-farm businesses & 44 & 59 & 38 \\
Less income from crop farming & 38 & 10 & 49 \\
Less work or lower wages for farm workers & 36 & 35 & 36 \\
Less income from domestic migrants & 33 & 30 & 34 \\
Less income from international migrants & 12 & 9 & 13 \\
Less income from livestock/fish farming & 7 & 4 & 9 \\
Directly citing COVID 19 & 6 & 1 & 7 \\
\hline Observations, communities & 308 & 85 & 223 \\
\hline
\end{tabular}

Source: MAPSA National COVID-19 Community Survey - June/July 2020.

Note: Responses based on question 'What are the main reasons for declines in income?' 
We then asked the community survey respondents to list what they perceived as the three most common mechanisms being used in their community to cope with these income losses. By far the most common coping mechanism mentioned was obtaining credit or loans. Help from government is mentioned in 20 percent of the communities. In 19 percent of the communities, community respondents believe that households are reducing food consumption and expenditures, similar to the 13 percent who report this coping mechanism in the household-level Rural-Urban Food Security Survey 2020 (Headey et al. 2020). Households are also using their savings (18 percent), Other coping mechanisms mentioned include collection of wild vegetables or fruits (9 percent), additional work (8 percent), help from donations (6 percent), or reduction of non-food expenditures (6 percent). Less frequently mentioned are the more dramatic measures of selling crop stocks, livestock, or agricultural assets (3 percent) or selling non-agricultural assets (3 percent).

Nearly all community respondents stated that their community received assistance from government or non-government actors between January and June 2020 (Table 4). In 95 percent of the communities, households were reported to have received food assistance from government. Individual food donations were more commonly reported for urban communities (42 percent) as compared to rural communities (13 percent). Food assistance from both international and local relief organizations was reported much less frequently. Non-food assistance (cash or in-kind non-food items) was also reported, but in a much smaller share of the communities in our sample (13 percent). In a quarter of the communities, respondents perceived that some of the residents were able to participate in food- or cash-for-work schemes.

Table 4: Food and non-food assistance, percent of communities reporting

\begin{tabular}{lrrrrrrrr} 
& Total & Urban & Rural & South & Dry Zone & $\begin{array}{c}\text { South- } \\
\text { East }\end{array}$ & North & West \\
\hline Food assistance & 96 & 99 & 96 & 98 & 100 & 94 & 89 & 91 \\
$\quad$ Government & 95 & 98 & 95 & 98 & 99 & 94 & 85 & 91 \\
International relief organization & 3 & 4 & 2 & 4 & 1 & 3 & 4 & 0 \\
Local relief organization & 7 & 12 & 5 & 6 & 7 & 13 & 6 & 9 \\
$\quad$ Individual food donations & 21 & 42 & 13 & 20 & 28 & 19 & 11 & 0 \\
Non-food assistance & 13 & 16 & 12 & 10 & 16 & 19 & 13 & 0 \\
$\quad$ Government & 7 & 8 & 6 & 8 & 8 & 6 & 4 & 0 \\
$\quad$ International relief organization & 1 & 1 & 1 & 0 & 0 & 6 & 2 & 0 \\
Local relief organization & 3 & 6 & 2 & 1 & 3 & 3 & 7 & 0 \\
Individual non-food donations & 3 & 5 & 3 & 1 & 5 & 6 & 2 & 0 \\
Food/cash for work scheme & 24 & 16 & 27 & 26 & 25 & 19 & 30 & 0 \\
\hline Observations, communities & 308 & 85 & 223 & 93 & 118 & 32 & 54 & 11 \\
\hline
\end{tabular}

Source: MAPSA National COVID-19 Community Survey - June/July 2020.

Note: Responses based on the question 'Since January this year, has the government, or any other international or local relief organization or individuals provided any emergency food products, non-food products, or cash transfers to support households in this village/street from the ward?'.

There were several marked variations in reported assistance across geographies. Though residents in communities interviewed in both urban and rural areas were reached with food and nonfood assistance, work schemes more often benefited residents in rural communities than in urban communities (27 versus 16 percent) (Table 4). All Dry Zone communities we interviewed received food assistance as compared to 89 percent of the communities in the North. None of the 11 communities interviewed in the West reported receiving non-food assistance, but 19 percent of communities in the South-East reported non-food assistance. Finally, we find a high share of foodand cash-for-work schemes in the interviewed communities in the North (30 percent), South (26 percent), and South-East (25 percent), but we did not find such schemes in the West. 


\section{Agricultural production}

As agriculture is the single largest source of income for many Myanmar households, we inquired about disruptions to agricultural production and sales between January and June 2020. Questions about agricultural production were asked only to respondents in communities with farm households (223 communities). In 55 percent of these communities, respondents reported lower production in 2020 than normal (Table 5).

Table 5: Reduced agricultural production and trading challenges reported in communities with farming households, percent of communities reporting

\begin{tabular}{|c|c|c|c|c|c|c|c|c|}
\hline Since January this year, ... & Total & Urban & Rural & South & Dry Zone & $\begin{array}{l}\text { South- } \\
\text { East }\end{array}$ & North & West \\
\hline $\begin{array}{l}\text { Agricultural production was lower } \\
\text { than usual }\end{array}$ & 55 & 50 & 56 & 47 & 62 & 65 & 43 & 70 \\
\hline $\begin{array}{l}\text { It was more difficult for farmers to } \\
\text { sell their produce }\end{array}$ & 50 & 39 & 52 & 43 & 55 & 54 & 44 & 71 \\
\hline Observations, communities & 223 & 22 & 201 & 57 & 86 & 26 & 44 & 10 \\
\hline
\end{tabular}

Source: MAPSA National COVID-19 Community Survey - June/July 2020.

Note: Responses based on two questions: (1) "Since January this year (round 1), has agricultural production by farmers in your community been lower than normal?"; (2) "Since January this year (round 1), has it been more difficult for farmers to sell their produce?"

In communities where production was lower than normal (123 out of 223 communities), we asked respondents to list up to three reasons for lower production. The main reason mentioned was adverse weather (79 percent). Pests (37 percent) and limited water supply (7 percent) were also mentioned. None of these three factors are related to the COVID-19 pandemic (Figure 4).

Figure 4: Main challenges causing reduced agricultural production, January to June 2020

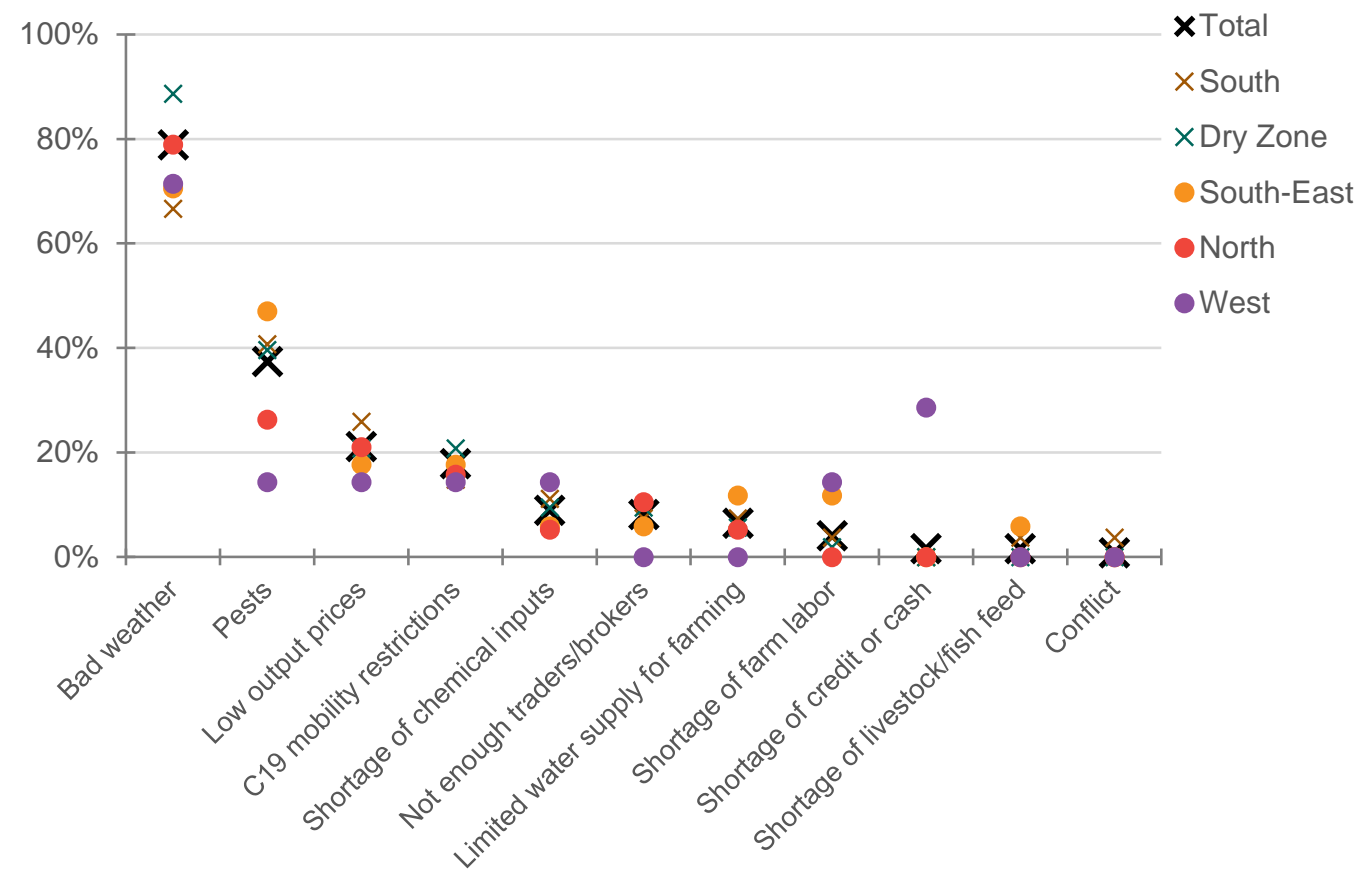

Source: MAPSA National COVID-19 Community Survey - June/July 2020.

Note: Based on responses from the sub-sample of agricultural communities reporting production in 2020 was lower than normal (123 out of 223). Responses based on the question 'What are the main reasons why agricultural production has been seriously disrupted?'.

However, other reasons cited for reduced agricultural production are likely directly or indirectly linked to the pandemic: low output prices (21 percent), COVID-19 related mobility restrictions (18 percent), shortage of inputs (9 percent), fewer traders or brokers for agricultural produce (7 percent), and a shortage of farm labor (4 percent). In total, 24 percent of communities with agricultural producers (53 out of 223 communities) and 43 percent of these communities that 
reported lower production than normal cite at least one constraint that might be related to the COVID-19 pandemic.

Most challenges to agricultural production were reported with similar frequencies across different areas of the country. However, bad weather was more frequently mentioned as a key constraint in the Dry Zone (Figure 4). Shortage of credit was a key constraint mentioned by 29 percent of communities in the West, but was less frequently reported elsewhere.

In half of the 223 agricultural communities surveyed, respondents stated that farmers faced more challenges than usual to sell their produce. Among those facing difficulties selling produce, 61 percent directly reported mobility restrictions due to COVID-19 (Figure 5). Two-thirds reported low output prices or fewer traders or brokers than usual, both of which could be consequences of COVID-19. Communities in the West were particularly affected by a lack of traders (100 percent). In contrast, the agricultural sales of most communities in the South-East were not as adversely affected by COVID-19 mobility restrictions as was reported in other parts of the country. Similarly, communities in the South mentioned low output prices and a lack of traders as challenges they faced in selling their produce less frequently than did respondents elsewhere.

Figure 5: Challenges to sales of agricultural products in communities reporting having difficulties selling their produce, January to June 2020

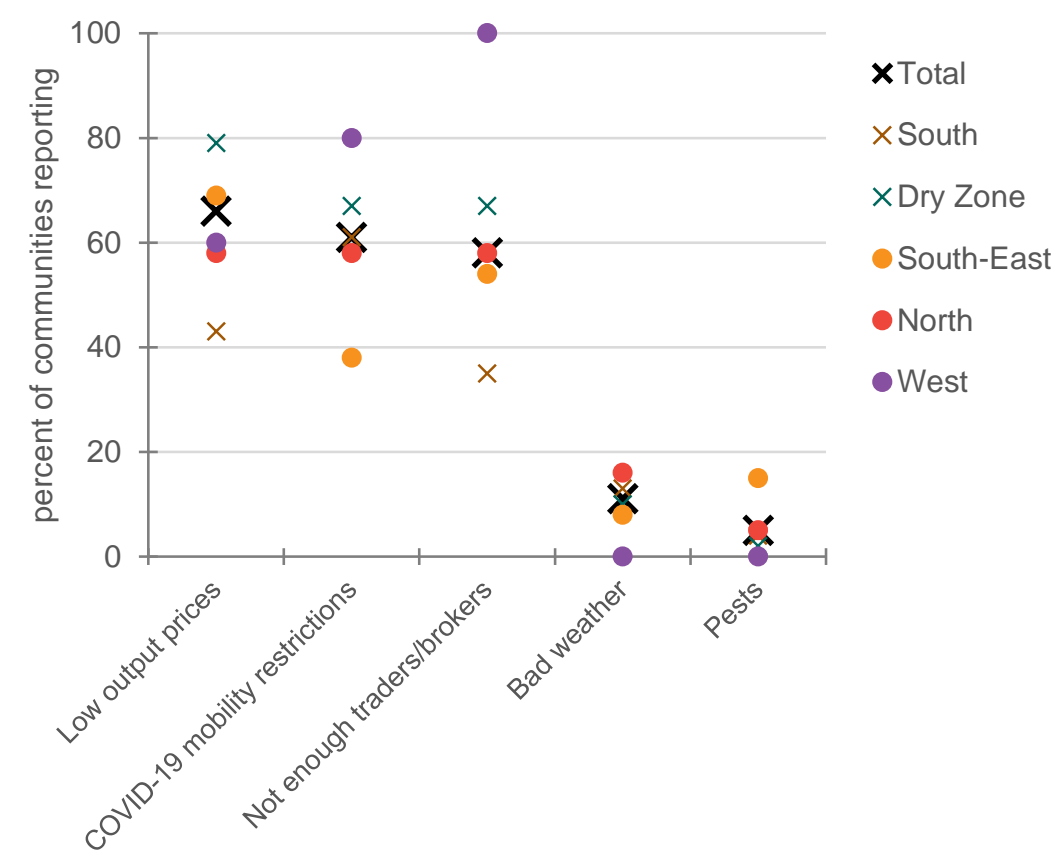

Source: MAPSA National COVID-19 Community Survey - June/July 2020.

Note: Responses based on the question 'What are the main reasons why agricultural sales activities have been seriously disrupted?'

\section{Migration and remittances}

Remittances contribute to the income of a significant share of households in Myanmar. Prior to COVID-19, respondents estimated that, on average, 9 percent of households in their community received remittances from an international migrant and 11 percent from domestic migrants (Table 6). Many of these households are likely to have witnessed a significant drop in remittance income due to COVID-19 effects.

Both restrictions on mobility and sharp reductions in employment opportunities led many migrants to return home during the first half of 2020. Others lost their jobs but were unable to return from where they were working. In each community, on average 2 female and 3 male international migrants 
returned and 4 female and 5 male domestic migrants returned. Despite the recent easing of restrictions on mobility, except for some communities in the West, no residents have yet left for international labor opportunities. Domestic migration has resumed with both men and women now again leaving their villages for work elsewhere in Myanmar.

Table 6: Changes in migration and remittances since January 2020

\begin{tabular}{|c|c|c|c|c|c|c|c|c|}
\hline & All & Urban & Rural & South & $\begin{array}{l}\text { Dry } \\
\text { Zone }\end{array}$ & $\begin{array}{l}\text { South } \\
\text { East }\end{array}$ & North & West \\
\hline $\begin{array}{l}\text { In January, households in community who received } \\
\text { remittances from an international migrant in January, \% }\end{array}$ & 9 & 8 & 9 & 9 & 7 & 16 & 9 & 6 \\
\hline $\begin{array}{l}\text { Since January, international migrants who returned and } \\
\text { remained in village, average number }\end{array}$ & 5 & 4 & 5 & 4 & 4 & 14 & 6 & 1 \\
\hline Men, average number & 3 & 3 & 3 & 2 & 2 & 8 & 4 & 1 \\
\hline Women, average number & 2 & 1 & 2 & 1 & 1 & 6 & 2 & 0 \\
\hline $\begin{array}{l}\text { In January, households in community who received } \\
\text { remittances from elsewhere in Myanmar, \% }\end{array}$ & 11 & 6 & 13 & 12 & 14 & 3 & 6 & 18 \\
\hline $\begin{array}{l}\text { Since January, domestic migrants in community who } \\
\text { returned to village, average number }\end{array}$ & 8 & 4 & 10 & 11 & 9 & 3 & 5 & 9 \\
\hline Men, average number & 5 & 3 & 5 & 6 & 5 & 2 & 3 & 5 \\
\hline Women, average number & 4 & 3 & 5 & 5 & 5 & 1 & 3 & 6 \\
\hline $\begin{array}{l}\text { In June, villagers who left village for international } \\
\text { migration, average number }\end{array}$ & 0 & 0 & 1 & 0 & 0 & 0 & 0 & 5 \\
\hline $\begin{array}{l}\text { In June, villagers who left village for domestic migration, } \\
\text { average number }\end{array}$ & 7 & 3 & 8 & 10 & 8 & 1 & 1 & 12 \\
\hline Men, average number & 3 & 1 & 4 & 5 & 4 & 1 & 1 & 5 \\
\hline Women, average number & 3 & 1 & 4 & 5 & 4 & 1 & 1 & 7 \\
\hline Observations, communities & 308 & 85 & 223 & 93 & 118 & 32 & 54 & 11 \\
\hline
\end{tabular}

Source: MAPSA National COVID-19 Community Survey - June/July 2020.

Note: Responses based on various questions on remittance dependency, return migration and expected out-migration.

\section{Health and water accessibility}

The COVID-19 crisis in Myanmar has had grave impacts on the economy, but the direct health impacts have been limited due to the small number of infections. However, it is possible that disruptions to health systems could lead to indirect adverse health impacts due to increased incidence of more common diseases, such as diarrhea, malaria, or respiratory illnesses. However, this does not appear to have happened thus far. Very few survey respondents believed that their communities had experienced higher rates of sick adults compared to the same time last year (1 percent). None reported higher rates of sick children. Indeed, one-third of communities reported fewer adults and children being sick this year.

Table 7: Perceptions of disruptions to health services and health-seeking behavior, percent of communities reporting

\begin{tabular}{|c|c|c|c|c|c|c|c|c|}
\hline & All & Urban & Rural & South & $\begin{array}{l}\text { Dry } \\
\text { Zone }\end{array}$ & $\begin{array}{l}\text { South } \\
\text { East }\end{array}$ & North & West \\
\hline $\begin{array}{l}\text { Cannot visit health facilities due to COVID-19 related } \\
\text { restrictions. }\end{array}$ & 18 & 24 & 16 & 20 & 19 & 19 & 13 & 18 \\
\hline $\begin{array}{l}\text { Choose not to visit health facilities due to fear of } \\
\text { contracting COVID-19 }\end{array}$ & 19 & 24 & 17 & 26 & 18 & 16 & 13 & 18 \\
\hline Medication scarcer due to the COVID-19 disruptions & 38 & 33 & 40 & 38 & 32 & 38 & 54 & 27 \\
\hline Observations, communities & 308 & 85 & 223 & 93 & 118 & 32 & 54 & 11 \\
\hline
\end{tabular}

Source: MAPSA National COVID-19 Community Survey - June/July 2020.

Note: Responses based on three questions: (1) "In the village/ your street from the ward, are there any people who would like to visit health facilities or healthcare practitioners but are not allowed to, due to the COVID-19 related restrictions?" (2) "In the village/ your street from the ward, are there any people who could visit the health facilities or healthcare practitioners, but they choose not to go there due to the fear of contracting the virus?" (3) "Is any medication more scarce or difficult to find compared to normal times, due to the virus?" 
However, mobility restrictions and other precautionary measures to prevent the spread of COVID-19 did affect access to health services (Table 7). In nearly one out of five communities, respondents perceived that people could not easily visit health facilities, whether within our outside of the community, perhaps reflecting the fact that in some instances doing so may have required obtaining permission from the ward/village leader. Moreover, residents in 19 percent of the communities were reported to have self-restricted their visits to health facilities due to fear of contracting the virus. These restrictions and self-restrictions are found at higher rates in urban wards than in rural villages. Access to and supply of medication was also more difficult than usual in 38 percent of the communities, but at higher rates in rural areas (40 percent) compared to urban wards (33 percent). Despite the dry season, most communities (94 percent) had enough water available, which is critical to maintain good hygienic practices.

\section{Policy implications}

This community survey explored the economic and social impacts of COVID-19 in a wide range of rural and urban communities in Myanmar as well as other major shocks affecting local communities. The statistics presented in this report should be considered as indicative for our sample but may not be representative for Myanmar or relevant subcategories. Table 8 provides a summary of major findings and policy recommendations.

Table 8. Summary of findings from first round of the National COVID 19 Community Survey and policy implications, by thematic domain

Domain

COVID-19

prevention

\section{Agricultural production \& marketing}

Key Findings

- Nearly all communities implemented a range of COVID-19 prevention measures, with the most common being curfews, restrictions on social activities, and restrictions or conditions on entry into the village/ward.

- Potentially more economically costly restrictions on leaving the village/ward for shopping or trade were reported in half of communities.

- Most communities reported that they closely followed COVID-19 regulations.

Economic -COVID-19 was reported to have caused widespread impacts \& social income losses.

protection - Unskilled laborers were one of the most affected groups.

- By far the most common coping mechanism was obtaining credit or a loan.

- Reducing food spending was reported in 20 percent of communities.

- Some communities raised concerns about putting children to work.

- Individual food donations were commonly reported in urban areas (42 percent).

- Food/cash for work schemes were present in onequarter of communities.

- 80 percent of farming communities report bad weather as a major agricultural constraint, followed by pests and constraints related to COVID-19.

- Related to COVID-19 constraints, half of communities stated that it is now more difficult for farmers to sell their produce.

- Major barriers to selling produce were low output prices, mobility restrictions, and inadequate traders/brokers. These problems appeared more pronounced in Rakhine and Chin.
Policy Implications

- Continue monitoring COVID-19 prevention measures to ensure adherence.

- Standardize and regulate appropriate procedures for clear communication to local leaders and public.

- Adopt safety procedures to make travel for economic activities more feasible

- Social protection mechanisms need to be expanded rapidly, striking a balance between short term immediacy and longer-term sustainability and efficiency.

- Social protection should target unskilled workers, such as through food/cash for work schemes.

- Social protection agencies should examine equity of assistance across regions.

- More research is needed on private philanthropy.

- MOALI and its development partners should closely monitor weather and pestilence in 2020.

- Relevant agencies should establish more regular and sustained monitoring of farm sector.

- COVID-19 prevention measures should minimize disruption to agricultural production, trade, and marketing. 


\begin{tabular}{|c|c|c|}
\hline Domain & Key Findings & Policy Implications \\
\hline $\begin{array}{l}\text { Migration \& } \\
\text { remittances }\end{array}$ & $\begin{array}{l}\text { - There is widespread dependence on remittances from } \\
\text { domestic and international migration for income. } \\
\text { - Many households lost income from declining } \\
\text { remittances. COVID-19 led many migrants to return } \\
\text { home during the first half of } 2020 \text {. } \\
\text { - International migration remains seriously disrupted, but } \\
\text { domestic migration for men and women has resumed } \\
\text { with recent easing of mobility restrictions and increasing } \\
\text { economic activity }\end{array}$ & $\begin{array}{l}\text { - Job creation and enterprise } \\
\text { development schemes for migrant } \\
\text { workers should be prioritized. } \\
\text { - Food/cash for work schemes should be } \\
\text { made available to returning migrants. }\end{array}$ \\
\hline Health services & $\begin{array}{l}\text { - There are few signs that communities are experiencing } \\
\text { higher than usual morbidities. } \\
\text { - Visits to health facilities have been lower due to } \\
\text { COVID-19 related restrictions. } \\
\text { - Households report avoiding health care visits for fear of } \\
\text { contracting COVID-19. }\end{array}$ & $\begin{array}{l}\text { - Remove barriers to health-related } \\
\text { travel and clearly communicate this } \\
\text { policy to communities. } \\
\text { - Use community messaging to } \\
\text { encourage appropriate health-seeking } \\
\text { behavior. }\end{array}$ \\
\hline
\end{tabular}

Source: Authors' construction.

Note: MOALI = Ministry of Agriculture, Livestock, and Irrigation.

Managing COVID-19 requires achieving a careful balance between necessary steps to prevent the spread of the disease and minimizing economic disruption from any preventative measures. Our survey shows that almost all Myanmar communities have taken a range of preventative steps, including steps that may be disruptive to local economies. Consistent with this, many farming communities cite COVID-19 related challenges in selling their produce, but the vast majority also cite weather-related problems as well as pests; shocks that are likely compounding the adverse effects of COVID-19 on the rural economy. Almost all communities cited unskilled workers as an especially vulnerable group whose incomes have been adversely affected by COVID-19.

These results - and those of other studies assessing the welfare impacts of the COVID-19 crisis in Myanmar (Diao et al. 2020; Headey et al. 2020) - suggest that the country faces a significant social protection challenge. Prior to the onset of COVID-19, the Government of Myanmar had already set up of several social protection schemes, though at a relatively limited scale compared to the large need for social protection during the COVID-19 crisis. Thus, the government's COVID-19 Emergency Response Plan proposed a number of interventions to reduce the adverse impacts of COVID-19 on households, including food transfers, low interest rate loans, electricity subsidies, and extra payments for pregnant women, mothers of young children, and pension recipients (GoM 2020). Along with household survey results (Headey et al. 2020), our results suggest that there may be new groups of poor, including households that have lost domestic or overseas migrants and their remittance incomes (Diao and Mahrt 2020b). The ongoing efforts to scale up existing social protection measures as well as establish new efforts will be critical in supporting all vulnerable households in the face of this crisis and in ensuring a successful economic recovery.

The complex economic and social impacts of COVID-19, as well as other widespread shocks related to climate change and pests, emphasize the need for high frequency monitoring of different communities in Myanmar both during the COVID-19 crisis and over the longer term. We thus recommend that the Government of Myanmar and its development partners consider a long-term strategy for monitoring poverty, malnutrition, coping strategies, resilience, and exposure to the different shocks that poor and vulnerable communities frequently face. 


\section{References}

CSO (Central Statistical Organization), UNDP (United Nations Development Programme), and World Bank. 2020. Myanmar Living Conditions Survey 2017: Socio-economic Report. Nay Pyi Taw and Yangon, Myanmar: Ministry of Planning, Finance, and Industry, UNDP, and World Bank.

Diao, X., and K. Mahrt. 2020a. Assessing the Impacts of COVID-19 on Household Incomes and Poverty in Myanmar. A microsimulation approach. Myanmar Strategy Support Program Working Paper 02. Yangon: International Food Policy Research Institute.

Diao, X., and K. Mahrt. 2020b. Assessing the Impacts of COVID-19 in Myanmar on Household Incomes and Poverty Due to Declines in Remittances. Myanmar Strategy Support Program Policy Note 06. Yangon: International Food Policy Research Institute.

Diao, X., N. Aung, W.Y. Lwin, P.P. Zone, K.M. Nyunt, and J. Thurlow. 2020. Assessing the Impacts of COVID-19 on Myanmar's Economy. A Social Accounting Matrix (SAM) Multiplier Approach. Myanmar Strategy Support Program Working Paper 01. Yangon: International Food Policy Research Institute.

Fang, P., B. Belton, H.E. Win, and X. Zhang. 2020. Monitoring the Impact of COVID-19 in Myanmar: Yangon Peri-urban Poultry Farmers. IFPRI Myanmar Strategy Support Program Policy Notes 11, 13, 19, 21, and 28. Yangon: International Food Policy Research Institute.

Goeb, J., D. Boughton, and M.K. Maredia. 2020. Monitoring the Impact of COVID-19 in Myanmar: Agricultural Input Retailers. Myanmar Strategy Support Program Policy Notes 8, 15, and 22. Yangon: International Food Policy Research Institute.

Goeb, J., D. Boughton, M.K. Maredia, A.M. Zu, and N.L.K. Synt. 2020. Monitoring the Impact of COVID-19 in Myanmar: Agricultural Commodity Traders. Myanmar Strategy Support Program Policy Note 10. Yangon: International Food Policy Research Institute.

GoM (Government of the Republic of the Union of Myanmar). 2020. Overcoming as One: COVID-19 Economic Relief Plan. Nay Pyi Taw: Government of the Republic of the Union of Myanmar.

Headey, D., S. Goudet, I. Lambrecht, T.Z. Oo, E.M. Maffioli, E. Field, and R. Toth. 2020. Poverty and food insecurity during COVID-19: Evidence from the COVID-19 Rural and Urban Food Security Survey (RUFSS) - June and July 2020 round. Myanmar Strategy Support Program Policy Note 27. Yangon: International Food Policy Research Institute.

Minten, B., T.Z. Oo, D. Headey, I. Lambrecht, and S. Goudet. 2020. Monitoring the impacts of COVID-19 in Myanmar: Food Vendors - June/July 2020 survey round. Myanmar Strategy Support Program Policy Note [forthcoming]. Yangon: International Food Policy Research Institute.

Takeshima, H., T.H. Win, and I. Masias. 2020a. Monitoring the Impact of COVID-19 in Myanmar: Mechanization Service Providers. Myanmar Strategy Support Program Policy Notes 7, 12, and 17. Yangon: International Food Policy Research Institute.

Takeshima, H., T.H. Win, and I. Masias. 2020b. Monitoring the Impact of COVID-19 in Myanmar: Agricultural Equipment Retailers. Myanmar Strategy Support Program Policy Notes 9, 16, and 18. Yangon: International Food Policy Research Institute. 


\section{Appendix}

Appendix Table A.1 Age, gender, and occupation of community survey respondents

\begin{tabular}{|c|c|c|c|}
\hline & All & Urban & Rural \\
\hline Age, years & 44 & 43 & 45 \\
\hline Years lived in community & 35 & 30 & 37 \\
\hline Households in community that respondent knows, $\%$ of all households & 84 & 72 & 89 \\
\hline Female, \% & 43 & 68 & 33 \\
\hline \multicolumn{4}{|l|}{ Occupation, \% of respondents } \\
\hline Farmer - own farm & 47 & 5 & 63 \\
\hline Other unskilled labor & 11 & 19 & 8 \\
\hline Craftsman & 6 & 11 & 4 \\
\hline Other service provider & 6 & 17 & 2 \\
\hline Broker's sale center business & 3 & 7 & 1 \\
\hline Farm worker & 3 & 0 & 4 \\
\hline Food processing worker & 3 & 5 & 2 \\
\hline Trader & 3 & 3 & 4 \\
\hline Retail salesperson & 3 & 6 & 2 \\
\hline Government professional & 3 & 3 & 3 \\
\hline Homemaker & 3 & 6 & 1 \\
\hline Clerical/office worker & 2 & 5 & 1 \\
\hline Teacher & 2 & 1 & 2 \\
\hline Mining/construction worker & 2 & 4 & 1 \\
\hline Driver/transportation & 2 & 5 & 1 \\
\hline Medical professional & 1 & 1 & 1 \\
\hline Other professional & 1 & 2 & 0 \\
\hline Factory worker & 0 & 1 & 0 \\
\hline Domestic worker/cleaner & 0 & 1 & 0 \\
\hline Observations, respondents & 561 & 152 & 409 \\
\hline
\end{tabular}

Source: MAPSA National COVID-19 Community Survey - June/July 2020

Appendix Table A.2. Reported main livelihood in communities and remoteness of communities

\begin{tabular}{lcrc}
\hline & All & Urban & Rural \\
\hline Main livelihood reported, \% of communities & 30 & 4 & 40 \\
Rice farming & 26 & 0 & 35 \\
Farming of other crops & 1 & 0 & 1 \\
Livestock farming & 0.3 & 0 & 0 \\
Fish farming & 4 & 1 & 5 \\
Fishing & 4 & 7 & 3 \\
Non-farm businesses & 1 & 1 & 1 \\
Farm wage labor (in crop, fish, and livestock farm) & 14 & 32 & 7 \\
Non-farm wage labor (e.g. factory work, manual labor) & 7 & 22 & 1 \\
Petty trade/ street vending & 1 & 4 & 0 \\
Government/military & 6 & 18 & 2 \\
Services or retail & 4 & 12 & 1 \\
Professional/clerical & 2 & 0 & 3 \\
\hline Remittances from international workers & $\mathrm{n} / \mathrm{a}$ & $\mathrm{n} / \mathrm{a}$ & 11 \\
\hline Remoteness: Distance to nearest town (miles) & 308 & 85 & 223 \\
\hline Observations, communities & & & 2 \\
\hline
\end{tabular}

Source: MAPSA National COVID-19 Community Survey - June/July 2020

Note: $\mathrm{n} / \mathrm{a}=$ not applicable. 


\section{ABOUT THE AUTHOR(S)}

Isabel Lambrecht is a Research Fellow in the Development Strategy and Governance Division (DSGD) of the International Food Policy Research Institute (IFPRI), based in Yangon. Derek Headey is a Senior Research Fellow with the Food Consumption and Nutrition Division of IFPRI, based in Yangon. Than Zaw Oo is a Research Analyst with DSGD of IFPRI, based in Yangon. Sophie Goudet is an independent nutrition researcher and consultant to IFPRI, based in Yangon.

\section{ACKNOWLEDGMENTS}

This work was undertaken as part of the Myanmar Agricultural Policy Support Activity (MAPSA) led by the International Food Policy Research Institute in partnership with Michigan State University. Funding support for this study was provided by the Myanmar office of the World Food Programme (WFP), the CGIAR Research Program on Policies, Institutions, and Markets, the United States Agency of International Development, and the Livelihoods and Food Security Fund.

The authors also thank the Innovations for Poverty Action (IPA) Myanmar office, BC Finance, Mandalay Yoma Solar Energy, Mawk Kon, and Zin Wai Aung for their support with the survey. We also thank staff of the Myanmar office of WFP for constructive comments and suggestions.

INTERNATIONAL FOOD POLICY RESEARCH INSTITUTE

1201 Eye St, NW I Washington, DC 20005 USA T. +1-202-862-5600 | F. +1-202-862-5606 ifpri@cgiar.org www.ifpri.org | www.ifpri.info
IFPRI-MYANMAR

No. 99-E6 U Aung Kein Lane Than Lwin Road, Bahan Township Yangon, Myanmar IFPRI-Myanmar@cgiar.org www.myanmar.ifpri.info
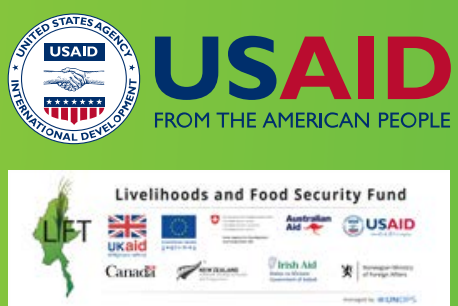

The Myanmar Strategy Support Program (Myanmar SSP) is led by the International Food Policy Research Institute (IFPRI) in partnership with Michigan State University (MSU). Funding support for Myanmar SSP is provided by the CGIAR Research Program on Policies, Institutions, and Markets; the Livelihoods and Food Security Fund (LIFT); and the United States Agency for International Development (USAID). This publication has been prepared as an output of Myanmar SSP. It has not been independently peer reviewed. Any opinions expressed here belong to the author(s) and do not necessarily reflect those of IFPRI, MSU, LIFT, USAID, or CGIAR. 